be remombered that graduate teaching is far more developed than it is in the U.K., and that the first degree in science is taken at a lower level than it is in Britain.

The report itself is critical of the way in which the funds are dispersed leading to a wider and widening difference in quality between the top and the bottom. On the whole the agencies responsible for providing the funds take the view that their money must be most effectively spent and therefore the better institutions are more favoured. All this can lead to the business of grantsmanship on a really big scale, particularly so when the salary of a member of staff may partially depend on his personally getting support from the agencies.

There is so much information in the report that it is impossible to comment completely, but since the United States is more inelined to engage in experiments of this kind than we do in Britain, it is extremely valuable to have the results of such a survey so that we in Britain may have the benefit of the effect of these methods of working in determining our own domestic programmes and in avoiding errors of judgment which can become of great academic importance.

H. W. Melvilile

\section{A JUBILEE TRIBUTE}

\section{Community of Universities}

An Informal Portrait of the Association of Universities of the British Commonwealth 1913-1963. By Sir Eric Ashby. Pp. viii +118 . (London: Cambridge University Press, 1963.) 12s. $6 d$.

7 HIS slim but important volume was written to herald the ninth quinquennial Congress of the Association of Universities of the British Commonwealth (held in London in July) and in anticipation of the granting of a Royal Charter to the (renamed) Association of Commonwealth Universities. Though based on such records as were not destroyed in 1940 , it is not strictly an 'official' history and is refreshingly free from the pious and arid pedantry which often mar such works.

The main purpose of the book is to trace the development of the organization under its different names from the conference convened by Gilbert Parker, member of parliament for Gravesend, in the rooms of the Royal Society in 1903 when it was resolved that: "it is desirable that such relations should be established between the principal teaching universities of the Empire as will secure that special or local advantages for study, and in particular for post-graduate study and research, be made as accessible as possible to students from all parts of the King's Dominions". The first Congress of the Universities of the Empire was held in 1912, a Universities Bureau established, and the publication of a Yearbook undertaken. The early years were not without growing pains; yet it was under the auspices of the Bureau that in 1917 a conference commended to the universities 'as a basis for common action' the desirability of establishing the Ph.D. degree.

Even as late as 1931 fears were expressed that the organization might attempt too much in the way of a regimentation of the universities. To-day, the Association is a thriving institution which enjoys the confidence of the universities and is recognized by them as indispensable. The latest edition of its $Y$ earbook runs to 1,825 pages and is a major work of academic reference (see Nature, 199, 316; 1963); the Association assists in the making of more than 900 overseas appointments annually; it plays a big part in the administration of the scholarship schemes of the Marshall Aid Commemoration Commission and the Commonwealth Scholarship and Fellowship Plan; it organizes the comprehensive quinquennial Congresses, smaller inter-congressional conferences in various parts of the world, and the annual Home Universities Conference; it provides a secretariat for the Committee of Vice-Chancellors and Principals : and, not loast, its office in Gordon Square is the Mecea to which the steps of countless academic visitors are directed whenever help and advice are needed.

For many readers a particularly interesting chapter will be the one on the Vice-Chancellors' Committee, a body about whose casual origins and present functions Sir Eric provides much invaluable information. Occasional meetings of groups of Vice-Chancellors or Principals can be traced back as far as 1887 . It was a simple matter of convenience that the Vice-Chancellors of the home universities were appointed in 1910 as a committee of the Bureau to take charge of the academic side of the 1912 Congress; and it was this perhaps that triggered off the proposal of W. M. Childs of Reading in 1912 for 'devising more effective machinery for joint action'. It was, however, a conference at the Foreign Office, convened in May 1918 by A. J. Balfour with the concurrence of H. A. L. Fisher to discuss the Ph.D. question, which really brought the Vice-Chancellors' Committee into being under the auspices of the Bureau. Since that date, the constitutional position of the Committee has several times been clarified and the range of the topics with which it has perforce to concern itself has grown immeasurably. Sir Eric's judgment on its present status and activities is worth quoting: "The Committee to-day is as informal as ever it was. But its influence is very great indeed. It rarely makes pronouncements, but the pronouncements it does make carry great weight. Far from infringing university autonomy the Committee is a powerful instrument for preserving it".

This book is a delight to read, with never a dull page. It has all the pithiness of style, sense of perspective and penetrating comment which we have long come to associate with Sir Eric's writing. The facts are marshalled with an easy mastery and the main themes never obscured. Especially valuable features are the extensive quotations from a number of vital documents (such as Balfour's letter of 1918) not easily accessible otherwise and the succinct summaries and comparisons of the topies discussed at the various Congresses. There are eight short appendixes (including one of brief biographies of some outstanding personalities in the history of the Bureau and the Association) and a short index.

For everyone involved in the work of universities at home or overseas or generally interested in their welfare this book should be regarded as essential reading. The fascinating story it unfolds should inspire in the universities a quiet confidence during the period when they live under the shadow of Robbins and afford them encouragement as they face the glare of whatever 'new deal' may await them. JAMES MOUNTTORD

\section{UNITS OF EVOLUTION}

\section{Animal Species and Evolution}

By Prof. Ernst Mayr. Pp. xiv + 797. (Cambridge, Mass.: The Belknap Press of Harvard University Press; London: Oxford University Press, 1963.) 70s. net.

THIS is a magistral book. It is certainly the most important study of evolution that has appeared for many years-perhaps even since the publication of The Origin of Species in 1859.

In any event, it resembles the Origin in focusing on the species as the key to evolutionary understanding. The species concept is certainly central, as Mayr shows in his chapter on the history of the subject. He reminds us that Darwin considered it a purely arbitrary one: "I look at the term as one given for the sake of convenience to a set of individuals closely resembling each other". For him the species had no objective existence. His prime concern was to show that they were not fixed, but could be "transformed"--in other words, evolve. Lin- 